JIKAP PGSD: Jurnal Ilmiah Ilmu Kependidikan

Vol,3. No,3. Tahun 2019

e-ISSN: 2597-4440 dan p-ISSN: 2597-4424

(c) (1) This work is licensed under a Creative Commons Attribution

4.0 International License

\title{
Pengaruh Model Pembelajaran Paired story telling Terhadap Keterampilan Menulis Karangan Narasi Pada Muatan Bahasa Indonesia Siswa Kelas V SD Negeri Kompleks IKIP I Kota Makassar
}

\author{
Nurhaedah $^{1}$, Muslimin ${ }^{2}$, Andini Kamal ${ }^{3}$ \\ ${ }^{123}$ PGSD FIP Universitas Negeri Makassar \\ Email: ${ }^{1}$ nurhaedah88@gmail.com \\ ${ }^{2}$ muslimin@gmail.com \\ 3andini.kamal@gmail.com
}

\begin{abstract}
Abstrak. Masalah dalam penelitian ini adalah rendahnya keterampilan menulis karangan narasi siswa kelas V SD Negeri Kompleks IKIP I Kota Makassar. Tujuan penelitian ini adalah untuk mengetahui: (1) gambaran model pembelajaran paired story telling di kelas V SD Negeri Kompleks IKIP I, (2) gambaran keterampilan menulis karangan narasi siswa pada muatan pelajaran bahasa Indonesia kelas V SD Negeri Kompleks IKIP I, dan (3) apakah model pembelajaran paired story telling berpengaruh terhadap keterampilan menulis karangan narasi siswa pada muatan pelajaran bahasa Indonesia kelas V SD Negeri Kompleks IKIP I. Pendekatan yang dilakukan adalah kuantitatif jenis penelitian quasy eksperiment berbentuk non-equivalent control group design. Variabel bebas dalam penelitian ini adalah model pembelajaran paired story telling sedangkan variabel terikat adalah keterampilan menulis karangan narasi. Jumlah populasi 93 siswa yaitu kelas Va sebanyak 46 siswa dan kelas Vb sebanyak 47 siswa. Sampel penelitian yaitu 75 siswa yang dilakukan dengan cara mengundi menggunakan teknik Simple Random Sampling dengan rumus Slovin yang taraf kesalahannya 5\%. Teknik pengumpulan data dengan menggunakan observasi, tes, dan dokumentasi. Teknik analisis data yang digunakan adalah analisis deskriptif dan analisis statistik inferensial. Hasil penelitian dapat disimpulkan bahwa, gambaran model pembelajaran paired story telling berlangsung secara baik dikarenakan kategori persentase untuk setiap pertemuannya meningkat. Sehingga dapat disimpulkan bahwa model pembelajaran paired story telling berpengaruh terhadap keterampilan menulis karangan narasi siswa pada muatan pelajaran bahasa Indonesia kelas V SD Negeri Kompleks IKIP I Kota Makassar.
\end{abstract}

Kata kunci: Model Pembelajaran Paired story telling, Keterampilan menulis Karangan Narasi

Abstract. The problem in this study was the low narrative essay writing skills of the fifth
grade students of the Complex Elementary School of IKIP I Makassar City. The research
objective was to find out: (1) the description of the paired story telling learning model in
class V of IKIP I Elementary School, (2) description of students 'narrative essay writing
skills on Indonesian language class V content of SD Negeri IKIP I Elementary School, and
(3) whether the paired story telling learning model influences students' narrative essay
writing skills on the fifth grade Indonesian language lesson at IKIP I Elementary School
The approach taken is quantitative research type quasy experiment It is in the form of non- 
JIKAP PGSD: Jurnal Ilmiah Ilmu Kependidikan

equivalent control group design. The independent variable in this study is the paired story telling learning model, while the dependent variable is narrative essay writing skills. The total population of 93 students namely the Va class was 46 students and the Vb class was 47 students. The research sample was 75 students conducted by drawing using the Simple Random Sampling technique with Slovin formula whose error rate was 5\%. Data collection techniques using observation, tests and documentation. The data analysis technique used is descriptive analysis and inferential statistical analysis using the Statistical Package for Social Scenario (SPSS) system Version 25.0. The results of the study can be concluded that, the description of the paired story telling learning model takes place well because the percentage category for each meeting increases. So that it can be concluded that the paired story telling learning model influences the students' narrative essay writing skills in the fifth grade Indonesian language learning content at the IKIP I Makassar Complex State Elementary School.

Keywords: Paired story telling learning model, narrative esay writing skills.

\section{PENDAHULUAN}

Setiap keterampilan berbahasa berhubungan erat dengan cara yang beraneka ragam. Untuk menguasai keterampilan berbahasa, dibutuhkan latihan yang intensif. Hal ini selaras dengan pernyataan bahwa "keterampilan menulis tidak akan datang secara otomatis, tetapi harus melalui latihan dan praktik yang banyak dan teratur" (Tarigan, 2013: 4). Dari ke empat keterampilan berbahasa, menulis merupakan salah satu keterampilan yang mempunyai peranan penting dalam kehidupan sebab dengan menulis, seseorang dapat berkomunikasi secara tidak langsung, dalam arti tidak secara bertatap muka dengan orang lain, dengan menulis seseorang dapat merekam segala peristiwa, pendapat, dan sebagai penyalur informasi dalam bentuk tulisan.

Salah satu kompetensi menulis yang harus dikuasai siswa di kelas adalah menulis karangan narasi. Muhlisch (2014) mengartikan karangan narasi merupakan suatu karangan yang menceritakan suatu kejadian secara runtut sesuai dengan urutan waktu (kronologis), melalui kegiatan menulis karangan narasi, siswa dilatih untuk menuangkan ide atau pun gagasan yang berupa pengalaman mereka dalam bahasa tulis sesuai dengan ejaan baku. Menulis karangan narasi dengan memperhatikan pilihan kata dan penggunaan ejaan merupakan salah satu kompetensi dasar dalam keterampilan menulis yang harus dikuasai oleh siswa di sekolah dasar khususnya kelas $\mathrm{V}$ hal ini termuat dalam kompetensi pengetahuan kelas $\mathrm{V}$ yaitu menyajikan teks narasi yang disajikan secara lisan dan tulis menggunakan aspek: apa, di mana, kapan, siapa, mengapa dan bagaimana (Kemendikbud, 2017). Siswa dituntut untuk menulis karangan dengan memperhatikan aspek-aspek yang diperlukan dalam menulis karangan narasi.

Berdasarkan hasil observasi yang dilakukan di SD Negeri Kompleks IKIP I Kota Makasaar selama KKN Kependidikan, menunjukkan masih banyak masalah yang dihadapi siswa maupun guru dalam proses pembelajaran. Hasil wawancara yang dilakukan pada masingmasing wali kelas $\mathrm{V}$ diperoleh informasi bahwa guru sudah mengajar dengan baik tetapi belum optimal sehingga siswa sulit menghasilkan suatu tulisan. Dari 93 jumlah siswa kelas V terdapat 39 siswa yang tidak mempunyai kemampuan menulis yang baik. Kesulitan siswa dalam menulis karangan antara lain: 1) siswa belum mampu mengembangkan karangan sesuai dengan topik/ tema yang diberikan guru; 2) siswa masih kesulitan dalam menuangkan ide atau gagasan ke dalam bentuk karangan; 3) pilihan diksi kurang tepat; 4) belum mampu mengembangkan kalimat yang efektif; dan 5) penggunaan ejaan dan tanda baca yang kurang tepat. Selain faktor dari siswa, juga terdapat beberapa faktor dari guru, yaitu: 1) guru cenderung berceramah sehingga siswa kurang berpartisipasi aktif dalam proses pembelajaran menulis; dan 2) sumber belajar yang digunakan guru hanya memanfaatkan buku paket dan LKS yang sudah diterbitkan para penerbit sehingga membosankan bagi siswa.

Keterampilan berbahasa yang memiliki peran penting dalam kehidupan, guru perlu menerapkan model pembelajaran yang dapat mengembangkan keterampilan menulis karangan 
narasi siswa. Salah satu model pembelajaran yang dapat diterapkan oleh guru untuk mengembangkan keterampilan menulis karangan narasi siswa adalah model pembelajaran kooperatif. Model pembelajaran kooperatif mengandung pengertian bekerjanya sejumlah siswa baik sebagai anggota kelas ataupun sebagai anggota kelompok yang menitik beratkan pada interaksi antara anggota yang satu dengan anggota lainnya dengan tujuan yang sama. Terdapat beberapa tipe dari model pembelajaran kooperatif dan peneliti menggunakan model pembelajaran paired story telling yang sesuai dengan materi menulis karangan narasi di sekolah dasar.

Model pembelajaran paired story telling menurut Lie (2014: 71) merupakan "model pembelajaran yang menggabungkan kegiatan membaca, menulis, mendengarkan dan berbicara". Siswa dirangsang untuk mengembangkan kemampuan berpikir dan berimajinasi. Buah pemikiran mereka akan dihargai sehingga siswa merasa terdorong untuk belajar. Selain itu, model pembelajaran ini konsepnya adalah siswa melakukan kejasama dalam menemukan kata kunci dalam teks bacaan kemudian kata kunci tersebut di kembangkan dengan imajinasi siswa dan mengkaitkannya dengan topik yang disediakan oleh guru. Model pembelajaran paired story telling diharapkan dapat membantu siswa mengorganisasikan ide atau gagasan menjadi sebuah karangan narasi yang baik. Merujuk dari beberapa peneliti sebelumnya yang dilakukan oleh Purnamasari (2012) memperoleh data hasil penelitian penerapan metode cooperative learning tipe paired story telling dapat meningkatkan hasil belajar siswa. Hasil penelitian yang dilakukan oleh Amaliya (2016) menunjukkan bahwa model pembelajaran paired story telling lebih efektif dengan keterampilan menyimak dibandingkan dengan model penugasan. Rata-rata keterampilan menyimak pada siswa kelas eksperimen yang menerapkan model paired story telling lebih tinggi dibandingkan kelas kontrol yang menerapkan model penugasan.

Berdasarkan paparan di atas, peneliti tertarik melakukan penelitian dengan judul Pengaruh Model Pembelajaran Paired story telling Terhadap Keterampilan Menulis Karangan Narasi Siswa pada Muatan Pelajaran Bahasa Indonesia Kelas V SD Negeri Kompleks IKIP I Kota Makassar.

\section{METODE PENELITIAN}

Pendekatan yang digunakan dalam penelitian ini adalah pendekatan kuantitatif dengan jenis penelitian quasi eksprimen berbentuk nonequivalent control design. Varibel utama dlam penelitian ini yaitu model pembelajaran paired story telling (variabel bebas ) dan keterampilan menulis narasi (variable terikat). Adapun desain penelitian adalah non-equivalent control design sebagai berikut:

Tabel 1: desian Penelitian

\begin{tabular}{lccc}
\hline $\begin{array}{c}\text { Kelompok } \\
\text { (kelas) }\end{array}$ & Pre-test & Treatment & Pos-test \\
\hline Eksprimen & $\mathrm{O}_{1}$ & $\mathrm{X}$ & $\mathrm{O}_{2}$ \\
\hline Kontrol & $\mathrm{O}_{3}$ & & $\mathrm{O}_{4}$
\end{tabular}

Sumber: Sugiyono (2017)

Definisi operasional Variabel

1. Model pembejaran paired story telling adalah pembelajaran yang dilakukan secara berpasangan guna membuat siswa aktif dan berperan lebih percaya diri dalam proses pembelajaran. Dengan cara guru menyampaikan kompetensi yang ingin dicapai, siswa bekerja secara berpasangan, setiap pasangan membuat kata kunci danmenukarkan kata kunci tersebut ke pasangannya dan masing-masing pasangan membuat karangan berdasarkan kata kunci tersebut dan terakhir presentasi.

2. Keterampilan Menulsi Narasi adalah skor yang diperoleh setelah postest dengan penilaian aspek terdiri dari kesesuain judul da nisi, keterpaduan kalimat, ejaan dan tanda baca, diksi atau pilihan kata, dan kerapian tulisan.

Populasi dalam penelitian ini keseluruhan siswa kelas V SD Inpres Komplek IKIP I dengan jumlah siswa 93 terdiri dari kelas Va dengan 46 siswa dan kelas $\mathrm{Vb}$ dengan 47 siswa. Adapun sampel yang digunakan menggunakan teknik random sampling dengan rumus slovin. Dari hasil pengampilan sampel diperoleh jumlah siswa kelas control adalah 37 dan kelas eksprimen sebanyak 38 siswa.

Adapun teknik pengumpulan data pada penelitian ini yaitu:

1. Observasi yang digunakan untuk mengamati terlaksananya model pembelajaran paired story telling

2. Tes berbentuk tes uraian yang tidak terbatas yaitu menulis karangan narasi. Adapun penghitungan skor menggunakan aspek-aspek 
menulis karangan narasi dengan jumlah skor setiap aspeknya adalah 4 dan skor keseluruhan untuk 5 aspek adalah 20. Tes yang digunakan tersebut untuk mengukur keterampilan menulis karangan narasi siswa yang nantinya akan diolah untuk mendapatkan sebuah informasi mengenai pengaruh model pembelajaran paired story telling terhadap keterampilan menulis karangan narasi siswa kelas V SD Negeri Kompleks IKIP I. Tes yang digunakan akan divalidasi sebelumnya oleh ahli dan validasi lapangan atau empiric.

Teknik analisis data yang digunakan pada penelitian ini adalah:

1. Analisis statistic deskriptif

Analisis statistik deskriptif dalam penelitian ini digunakan untuk mendeskripsikan keterampilan menulis karangan narasi siswa dalam pembelajaran bahasa Indonesia baik ketika diberi perlakuan penggunaan model pembelajaran paired story telling dalam pembelajaran kelas eksperimen maupun pembelajaran yang dilakukan secara langsung pada kelas kontrol. Statistik deskriptif yang dimaksud dalam penelitian ini adalah mendeskripsikan data perolehan keterampilan menulis karangan narasi siswa dalam penelitian seperti frekuensi, nilai rata-rata (mean), nilai tengah data (median), nilai yang sering muncul (modus), simpangan baku (standar deviation), nilai terendah data (minimal), nilai tertinggi data (maksimum), dengan menggunakan system Satististical Package for Social Sclense (SPSS) Versi 25.0.

Tabel 2: Pedoman Pengkategorian Keterampilan Menulis karangan narasi

\begin{tabular}{cc}
\hline Interval & Kategori \\
\hline $85-100$ & Sangat baik \\
\hline $70-84$ & Baik \\
\hline $56-69$ & Cukup \\
\hline $41-55$ & Kurang \\
\hline $0-40$ & Sangat kurang \\
\hline
\end{tabular}

Sumber: Arikunto (Suyadi, 2013)

2. Analisis statistic inferensial

a. Uji Asumsi prasyarat

Sebelum melakukan uji hipotesis terlebih dahulu dilakukan uji asumsi prasyarat dengan uji normalitas dan uji homogenitas. Untuk uji normalitas mengunakan uji kolmogrov-smirinov dimana jika $p$-value $>0.05$ maka dapat dikatakan data berdistibusi normal. Untuk uji homogenitas menggunakan Uji leavene dimana dimana jika $p$ value > 0.05 maka dapat dikatakan varian data homogeny.

b. Uji Hipotesis

Uji hipotesis menggunakan Independent Sample t-test untuk membandingkan dua kelompok mean dari dua sampel yang berbeda (independent). Prinsip dari uji ini adalah untuk mengetahui apakah ada perbedaan mean sampelnya sehingga sebelum diuji dengan independent samlpe t-test maka syaratnya data tersebut apabila nilai Sig. (2-Tailed) lebih kecil dari 0,05. Kemudian untuk menentukan hipotesis terpilih maka kita melihat dari ketentuan yaitu jika $t_{\text {hitung }} \leq \mathrm{t}_{\text {tabel }}$ maka $\mathrm{H}_{0}$ diterima dan $\mathrm{H}_{\mathrm{a}}$ ditolak dan jika $t_{\text {hitung }} \geq t_{\text {tabel }}$ maka $\mathrm{H}_{0}$ ditolak dan $\mathrm{H}_{\mathrm{a}}$ diterima.

\section{HASIL DAN PEMBAHASAN}

1. Data Pretest Siswa tentang Keterampilan Menulis Karangan Narasi Kelas Eksperimen dan kontrol

Pretest keterampilan menulis karangan narasi siswa pada kelas eksperimen dengan jumlah subjek penelitian sebanyak 37 orang dan pada kelas control dengan jumlah siswa 38 orang. Berikut data prestes kelas eksprimen dan kelas kontrol.

Tabel 3: Deskripsi skor nilai prestest siswa kelas eksprimen

\begin{tabular}{ccc}
\hline Statistik & \multicolumn{2}{c}{ Nilai statistic } \\
\cline { 2 - 3 } Deskriptif & Eksprimen & Kontrol \\
\hline Jumlah Sampel & 37 & 38 \\
\hline Nilai terendah & 46 & 46 \\
\hline Nilai Tertinggi & 88 & 88 \\
\hline Rata-rata & 71.35 & 71.03 \\
\hline Standar Deviasi & 10.714 & 11.125 \\
\hline Median & 71 & 71 \\
\hline Modus & 67 & 71 \\
\hline \multicolumn{3}{c}{ Dari table 3, rata-rata keterampilan menulis } \\
narasi adalah 71,35 yang berarti nilai prestest siswa \\
berada di sekitar nilai 71 , ini di dukung oleh \\
mediannya pada 71. & Dengan standar deviasi \\
10,714, hal ini menunjukkan bahwa data pretest \\
pada kelas eksprimen bervarian. Demikian juga \\
pada kelas control, data prestest bervarian artinya \\
tidak perbedaan pretset masing-masing kelas \\
dengan rata-rata 71.03 dan standar deviasi 11,125 \\
dengan nilai median 71. Keterampilan menulis \\
kedua kelas sama. Distribusi dan presentase skor \\
nilai pretset keterampilan menulis narasi siswa \\
pada kelas eksprimen sebagai berikut:
\end{tabular}


Tabel 4: Distriubusi Frekunesi Pretest kelas eksprimen dan kelas kontrol

\begin{tabular}{cccccc}
\hline \multirow{2}{*}{ Interval Nilai } & \multirow{2}{*}{ Kategori } & \multicolumn{2}{c}{ Eksprimen } & \multicolumn{2}{c}{ Kontrol } \\
\cline { 3 - 6 } & & Frekuensi & Presentase & Frekuensi & Presentase \\
\hline $85-100$ & Sangat baik & 3 & $7 \%$ & 4 & $11 \%$ \\
\hline $70-84$ & Baik & 19 & $52 \%$ & 19 & $50 \%$ \\
\hline $56-69$ & Cukup & 11 & $26 \%$ & 10 & $26 \%$ \\
\hline $41-55$ & kurang & 4 & $15 \%$ & 5 & $13 \%$ \\
\hline $0-40$ & Sangat kurang & - & - & - & - \\
\hline Jumlah & & 37 & $100 \%$ & 38 & $100 \%$ \\
\hline
\end{tabular}

Table 3 dan table 4 menunjukkan bahwa keterampilan menulis narasi siswa kelas $\mathrm{V}$ berada pada kategori yang baik yaitu diatas nilai 70 atau sekitar 59\% sudah dapat menulis karangan narasi dengan baik. Kemudian ada sekitar 15 siswa atau $41 \%$ yang masih belum maksimal dalam menulis karangan narasi. Hal yang sama pada kelas control. Sekitar $61 \%$ keterampilan menulis narasi sudah baik dan sekitar 39\% masih belum maksimal. Aspek yang menjadi kendala rata-rata dalam keterpaduan kalimat, diksi dan ejaan yang digunakan. Terkadang masih menggunakan Bahasa sehari-hari. Namun dilihat presentasi kelas eksprimen 59\% dan kelas control 61\%, hanya selisih $2 \%$ masih lebih baik kelas control, tetapi secara rata-rata kemampuan menulis narasi secara rata-rata tidak jauh berbeda, varian kedua kelas sama.

2. Data postest Siswa tentang Keterampilan Menulis Karangan Narasi Kelas Eksperimen dan kontrol

Postest keterampilan menulis karangan narasi siswa pada kelas eksperimen dengan jumlah subjek penelitian sebanyak 37 orang dan pada kelas control dengan jumlah siswa 38 orang. Berikut data posstes kelas eksprimen dan kelas kontrol.
Tabel 5: Deskripsi skor nilai prestest siswa kelas eksprimen

\begin{tabular}{ccc}
\hline Statistik & \multicolumn{2}{c}{ Nilai statistic } \\
\cline { 2 - 3 } Deskriptif & Eksprimen & Kontrol \\
\hline Jumlah Sampel & 37 & 38 \\
\hline Nilai terendah & 58 & 54 \\
\hline Nilai Tertinggi & 96 & 92 \\
\hline Rata-rata & 79 & 73.18 \\
\hline Standar Deviasi & 12.046 & 10.932 \\
\hline Median & 79 & 75 \\
\hline Modus & 71 & 71 \\
\hline
\end{tabular}

Dari table 5, rata-rata keterampilan menulis narasi adalah 79 yang berarti nilai postest siswa dengan 79. Dengan standar deviasi 12,714, hal ini menunjukkan bahwa data p0stest pada kelas eksprimen bervarian. Demikian juga pada kelas control, data postest bervarian dengan rata-rata 71.03 dan standar deviasi 11,125 dengan nilai median 75. Keterampilan menulis narasi kedua kelas sama-sama mengalami peningkatan. Untuk kelas eksprimen rentang nilai hasil keterampilan menulis narasi berada disekitar 66.954 - 91.046 sedangkan kelas control berada pada 62.248 81.046. Distribusi dan presentase skor nilai pretset keterampilan menulis narasi siswa pada kelas eksprimen sebagai berikut:

Tabel 6: Distriubusi Frekunesi Pretest kelas eksprimen dan kelas kontrol

\begin{tabular}{cccccc}
\hline \multirow{2}{*}{ Interval Nilai } & \multirow{2}{*}{ Kategori } & \multicolumn{2}{c}{ Eksprimen } & \multicolumn{2}{c}{ Kontrol } \\
\cline { 3 - 6 } & & Frekuensi & Presentase & Frekuensi & Presentase \\
\hline $85-100$ & Sangat baik & 12 & $33 \%$ & 5 & $13 \%$ \\
\hline $70-84$ & Baik & 19 & $51 \%$ & 19 & $50 \%$ \\
\hline $56-69$ & Cukup & 6 & $16 \%$ & 11 & $29 \%$ \\
\hline $41-55$ & kurang & - & - & 3 & $8 \%$ \\
\hline $0-40$ & Sangat kurang & - & - & - & - \\
\hline Jumlah & & 37 & $100 \%$ & 38 & $100 \%$ \\
\hline
\end{tabular}

Table 5 dan table 6 menunjukkan bahwa keterampilan menulis narasi siswa kelas $\mathrm{V}$ pada kelas eksprimen mengalami peningkatan, demikian juga pada kelas control. Namun secara deskripstif lebih baik kelas eksprimen daripada kelas control. Jumlah siswa yang belum tuntas dalam 
keterampilan menulis pada kelas control masih ada 3 orang. Hal ini dikarenakan mereka masih belum menyusun keterpaduan antar kalimat, diksi yang digunakan, Bahasa yang masih belum tersturktur dan kerapian tulisan serta kesesuain isi dengan judul. Pada kelas eksprimen, semua siswa berada dalam kategori baik dan tuntas secara keseluruhan. Ada 6 siswa yang berada pada kategori cukup. Aspek yang masih belum terpenuhi pada Bahasa yang digunakan dan kerapian tulisan serta diksi. Secara deskriptif, penerapan model pembelajaran paired story telling memberikan pengaruh dan dapat diterapkan pada pembelajaran Bahasa Indonesia khususnya keterampilan menulis karangan narasi.

3. Pengaruh Model Pembelajaran Paired story telling terhadap Keterampilan Menulis Karangan Narasi Siswa Kelas V SD Negeri Kompleks IKIP I

a. Uji Normalitas dan Homogintas.

Uji Normalitas pada penelitian ini menggunakan Kolmogorov-Smirnov. Data dikatakan berdistribusi normal apabila nilai probabilitas pada output Kolmogorov-Smirnov tes lebih besar daripada nilai $\alpha$ yang ditentukan, yaitu $5 \%(0,05)$.

Tabel 7: Hasil Uji Normalitas Data Pretest dan Posttest Kelas Eksperimen dan Kelas Kontrol

\begin{tabular}{lcl}
\hline \multicolumn{1}{c}{ Data } & \multicolumn{1}{c}{$\begin{array}{c}\text { Nilai } \\
\text { Probabilitas }\end{array}$} & Keterangan \\
\hline $\begin{array}{l}\text { Pretest Kelas } \\
\text { Eksprimen }\end{array}$ & $0,200>0.05$ & Normal \\
\hline $\begin{array}{l}\text { Pretest Kelas } \\
\text { Konrol }\end{array}$ & $0.200>0.05$ & Normal \\
\hline $\begin{array}{l}\text { Postest Kelas } \\
\text { Eksprimen }\end{array}$ & $0.200>0.05$ & Normal \\
\hline $\begin{array}{l}\text { Postest Kelas } \\
\text { Kontrol }\end{array}$ & $0.196>0.05$ & Normal \\
\hline
\end{tabular}

Selanjutnya Uji homogenitas dilakukan untuk mengetahui apakah data yang diperoleh dari kedua sampel homogen atau tidak. menggunakan Uji Levene. Data dikatakan homogen apabila nilai probabilitas pada output Levene Statistic lebih besar daripada nilai $\alpha$ yang ditentukan, yaitu $5 \%$ $(0,05)$

Hasil uji levene menunjukkan bahwa keterampilan menulis narasi siswa kelas $\mathrm{V}$ homogeny dengan nilai $\mathrm{F}=0.521$ lebih besar dari 0,05 .

\section{b. Uji Hipotesis}

Uji hipotesis menggunakan Independent Sample T-Test pada Posttest Kelas Eksperimen dan Kelas Kontrol. Analisis ini bertujuan untuk mengetahui perbedaan hasil keterampilan menulis karangan narasi siswa antara kelas yang mengikuti pembelajaran dengan menggunakan model pembelajaran paired story telling dan kelas yang mengikuti pembelajaran tanpa menggunakan model pembelajaran paired story telling. Adapun hasil analisis independent sample t-test nilai posttest kelas eksperimen dan posttest kelas kontrol sebagai berikut.

Tabel 8: Uji hipotesis Independent Sample T-test

\begin{tabular}{lcccc}
\hline \multicolumn{1}{c}{ Data } & T & df & Prob & Ket \\
\hline Postest & 2.191 & 73 & 0.032 & $0.032<0.05$ \\
kelas Eks & & & & \\
dan kelas & & & & \\
kontrol & & & & \\
\hline
\end{tabular}

Berdasarkan tabel 8, diperoleh informasi bahwa nilai probabilitas lebih kecil dari 0,05 . Hal ini menunjukkan bahwa terdapat perbedaan yang signifikan hasil keterampilan menulis karangan narasi siswa antara kelas yang mengikuti pembelajaran dengan menggunakan model pembelajaran paired story telling dan kelas yang mengikuti pembelajaran tanpa menggunakan model pembelajaran paired story telling. Jika nilai t hitung sebesar 2,191 dibandingkan dengan nilai $t$ tabel sebesar 1,993 dengan melihat nilai $\alpha=5 \%$ dan $\mathrm{df}=73$, maka $\mathrm{t}$ hitung memiliki nilai lebih besar dari t table.

Hasil penelitian pengaruh penggunaan model pembelajaran paired story telling terhadap keterampilan menulis karangan narasi siswa kelas V SD Negeri Kompleks IKIP I secara deskriptif memperlihatkan ada perubahan hasil keterampilan menulis narasi dengan jumlah siswa berhasil dengan presentase $84 \%$. Data ini didukung dengan analisis statistik inferensial bahwa terdapat perbedaan yang signifikan pengaruh penerapan model pembelajaran paired story telling. Hal ini menunjukkan model pembelajaran paired story telling mampu mengasah kemampuan dan keaktifan siswa dalam menulis karangan narasi. Siswa tidak merasa kesulitan dalam mengembangkan kata kunci yang mereka tulis. Hasil menulis karangan narasi siswa lebih baik dari sebelumnya setelah mendapatkan pembelajaran menulis karangan narasi dengan model 
pembelajaran paired story telling. Model pembelajaran paired story telling menjalin kerjasama dengan siswa lain sebagai sumber belajar di dalam kelompok heterogen. Kelebihan lain dari model pembelajaran paired story telling yaitu meningkatkan partisipasi siswa dalam proses pembelajaran, interaksi lebih mudah dan pembentukan kelompok menjadi lebih cepat dan mudah (Lie, 2014). Kata kunci yang dibuat siswa mampu menulis karangan narasi tanpa keluar dari pokok pembahasan sehingga menghasilkan tulisan yang singkat, padat, dan jelas. Hal ini sejalan dengan Hermawan dkk (2016) bahwa model pembelajaran paired story telling teruji meningkatkan keterampilan berbicara siswa. Berdasarkan hasil penelitian ini dan hasil penelitian sebelumnya, dapat disimpulkan bahwa model pembelajaran paired story telling berpengaruh terhadap keterampilan menulis karangan narasi siswa kelas V SD Negeri Kompleks IKIP I Kota Makassar. Penerapan model yang tepat dengan materi yang tepat akan memberikan hasil maksimal.

\section{SIMPULAN DAN SARAN}

Berdasarkan hasil penelitian yang dilakukan dapat disimpulkan beberapa hal antara lain:

1. Pelaksanaan model pembelajaran paired story telling pada kelas eksperimen berlangsung secara baik dikarenakan kategori persentase untuk setiap pertemuan meningkat.

2. Gambaran keterampilan menulis karangan narasi siswa kelas V SD Negeri Kompleks IKIP I pada kelas eksperimen lebih meningkat dibandingkan keterampilan menulis karangan narasi siswa pada kelas kontrol. Hal tersebut dibuktikan dengan nilai posttest pada kelas eksperimen berada pada presentase $84 \%$, sedangkan nilai posttest pada kelas kontrol berada pada presentase $63 \%$.

3. Penerapan model pembelajaran paired story telling berpengaruh sifinifikan terhadap keterampilan menulis karangan narasi siswa di kelas V SD Negeri Kompleks IKIP I Kota Makassar.

Adapun saran dalam penelitian yang diajukan oleh peneliti yaitu: dalam pelaksanaan proses pembelajaran sekolah maupun guru mampu menerapkan model pembelajaran yang efektif pada setiap materi yang diajarkan, salah satunya adalah penggunaan model pembelajaran paired story telling terhadap peningkatan keterampilan menulis siswa.

\section{DAFTAR RUJUKAN}

Amaliya, Isna. 2016. Keefektifan Model Pembelajaran Paired story telling Terhadap Keterampilan Menyimak Cerita Siswa SD Kelas V (Online). Skripsi. Universitas Negeri Semarang. Tersedia http://journal. Unnes.ac.id/pdf (April 2018)

Hermawan, Yoga, et al. 2016. Penerapan Model Pembelajaran Paired Story Teling untuk Meningkatkan Keterampilan Berbicara Pada Mata Pelajaran Bahasa Indonesia. Journal Pendidikan. Universitas Pendidikan Ganesha 4 (1): 6

Kemendikbud. 2016. Kompetensi Inti dan Kompetensi Dasar Pelajaran Bahasa Indonesia pada Pendidikan Dasar dan Menengah. Jakarta: Kemendikbud. 2017. Kompetensi Inti dan Kompetensi Dasar Pelajaran Bahasa Indonesia pada Pendidikan Dasar dan Menengah. Jakarta: Kemendikbud

Lie, Anita. 2014. Mempraktikkan Cooperative Learning di Ruang-Ruang Kelas. Jakarta: Grasindo.

Muslich, Masnur. 2014. Garis-Garis Besar Tatabahasa Baku Bahasa Indonesia. Bandung: PT. Refika Aditama.

Sugiyono. 2017. Metode Penelitian Pendidikan Pendekatan Kuantitatif, Kualitatif, dan $R \& D$. Bandung: Alfabeta.

Suyadi, 2013. Panduan Penelitian Tindakan Kelas Buku Panduan Wajib bagi Para Pendidik. Yogyakarta: DIVA Press

Tarigan, Henry Guntur. 2013. Menulis Sebagai Suatu Keterampilan Berbahasa. Bandung: Cv. Angkasa.

Purnamasari, Danik Ika. 2012. Penerapan Metode Cooperative Learning Tipe Paired story telling Untuk Meningkatkan Hasil Belajar Siswa Kelas V SD Negeri 3 Patihan Sidoharjo Sragen Pada Mata Pelajaran IPS Tahun 2012 (Online). Skripsi: Universitas Muhammadiyah Surabaya. Tersedia http://journal. Naskah Publikasi/pdf (April 2018) 
JIKAP PGSD: Jurnal Ilmiah Ilmu Kependidikan

Ramly \& Azis. 2008. Bahasa Indonesia. Makassar: Badan Penerbit Universitas Negeri Makassar.

Wibowo, Wahyu. 2010. Manajemen Bahasa Pengorganisasian Karangan Pragmatik dalam Bahasa Indonesia untuk Mahasiswa dan Praktisi Bisnis. Jakarta: PT. Gramedia Pustaka Utama.

Wijayanti, S. H., et al. 2015. Bahasa Indonesia Penyajian dan Karya Tulis Ilmiah. Jakarta: Rajagrafindo Persada 